\title{
Terapi Bekam Basah Terhadap Kadar Kolerterol Pada Penderita Hiperkolesterolemia di Klinik Holistic Centre Asy-Syafii Palembang
}

\author{
Dedi Pahrul $^{1}$, Abdul Syafei ${ }^{2}$ \\ 1,2 Prodi Ilmu Keperawatan STIK Siti Khadijah Palembang \\ Jalan Demang Lebar Daun Lorok Pakjo Palembang 30117 \\ Email: dedipahrul7@gmail.com
}

\begin{abstract}
Abstrak
Salah satu pengobatan non-farmakologis atau terapi komplementer penatalaksaan hiperkolesterolimia adalah terapi bekam, terapi ini dilakukan pada titik-titik meridian untuk menurunkan hiperkolesterolemia. Penelitian ini bertujuan untuk mengetahui pengaruh terapi bekam terhadap kadar kolesterol darah pada penderita hiperkolesterolimia di klinik Holistic Centre Asy-Syafii Palembang. Penelitian ini merupakan penelitian quasy ekspermental dengan one group pre test posttest. Populasi yang digunakan pada penelitian ini adalah seluruh penderita hiperkolesterolimia di klinik Holistic Care AsySyafii berjumlah 31 orang responden. Tehnik sampling yang digunakan adalah total sampling. Penelitian ini telah dilakukan pada tanggal 5 Oktober - 26 Desember 2020 bertempat di klinik Holistic Centre AsySyaafi. Hasil penelitian menunjukan bahwa terdapat perbedaan yang signifikan antara kadar kolesterol sebelum dan sesudah pemberian terapi bekam (p: 0.000). Maka dari itu disarankan untuk diadakan endidikan kesehatan kepada masyarakat tentang manfaat terapi bekam serta cara mengontrol kadar kolesterol darah.
\end{abstract}

Kata Kunci : Terapi Bekam, Kadar Kolesterol

\begin{abstract}
Cupping therapy was one of complementary therapies for the management of hypercholesterolemia, this therapy was performed on meridian points to reduce hypercholesterolemia. This study aimed to determine the effect of cupping therapy on blood cholesterol levels in hypercholesterolemic patients at the Asy-Syafii Holistic Center clinic in Palembang. This research was a quasi-experimental study with one group pre test posttest design. The population used in this study were all patients with hypercholesterolemia at the Holistic Care Asy-Syafii clinic totaling 31 respondents. The sampling technique used was total sampling. This research was conducted on $5^{\text {th }}$ October $-26^{\text {th }}$ December in 2020 at the Asy-Syaafi Holistic Center clinic. The results showed that there was a significant difference between cholesterol levels before and after cupping therapy ( $p$ : 0.000). Therefore, it was recommended that health education be held to the public about the benefits of cupping therapy and how to control blood cholesterol levels.
\end{abstract}

Keywords: Cupping Therapy, Cholesterol Levels 


\section{PENDAHULUAN}

Hiperkolesterol adalah faktor penyebab resiko kematian di usia muda. Banyak orang yang mengkonsumsi makanan tanpa mempertimbangkan senyawa apa yang terkandung di dalam makanan tersebut, salah satunya kadar kolesterol (Kemenkes, 2017).

Hiperkolesterolemia atau dislipidemia berperan penting dalam terjadinya aterosklerosis yang merupakan suatu proses degenerative dan factor resiko penyakit kardiovaskuler. Namun nilai total kolesterol tidak menjelaskan secara lengkap keadaan kolesterol seseorang. (Faizal, 2020).

Menurut Riskesdas tahun 2013, pada penduduk >15 tahun didapatkan kolesterol total abnormal dengan kategori borderline 200-239 mg/dl dan tinggi $>240 \mathrm{mg} / \mathrm{dl}$ sebesar $35,9 \%$, HDL rendah $22,9 \%$, LDL tidak optimal dengan kategori gabungan nearoptimal-borderline tinggi $60,3 \%$ dan kategori tinggi-sangat tinggi $15,9 \%$, trigliserida abnormal dengan kategori borderline tinggi $13,0 \%$ dan kategori tinggisangat tinggi $11,9 \%$. Pengobatan hiperkolesterolemia secara farmakologis dengan pemberian berbagai obat normolipidemia diantaranya golongan obat statin, fibrat, resin, inhibit atau absorpsi kolesterol selektif dan asam nikotinat.

Pengobatan hiperkolesterolemia saat ini belum efektif karena hampir $70 \%$ pasien hiperkolesterolemia di Indonesia gagal mencapai sasaran kadar kolesterol sesuai dengan panduan pengobatan, selain itu pula karena harga obatnya relatif mahal, sering terjadi kekambuhan dan menimbulkan efek samping yang lebih berbahaya (Price \& Wilson, 2015).

Salah satu pengobatan nonfarmakologis atau terapi komplementer penatalaksaan hiperkolesterolimia adalah terapi bekam, terapi ini dilakukan pada titiktitik meridian untuk menurunkan hiperkolesterolemia. Pemberian terapi bekam pada titik-titik meridian yang tepat maka akan meningkatan jumlah leukosit, limfosit dan sistem retikulo-endothelial, pelepasan ACTH, kortisol, endorphin, enkefalin dan faktor humoral lain yang juga menimbulkan efek anti peradangan, penurunan serum lemak trigliserida, fosfolipida, kolesterol total khususnya kolesterol LDL, merangsang lipolisis jaringan lemak dan menormalkan kadar glukosa dalam darah (Yani, 2015).

Berdasarkan hasil penelitian Fikri, et al., (2017) menunjukkan $\mathrm{p}=0,001$ dan dengan paired $\mathrm{t}$-test didapatkan nilai $\mathrm{p}=$ 0,003 . Hasil tersebut berarti bahwa terdapat efek signifikan terapi bekam terhadap penurunan kadar kolesterol. Lebih lanjut menurut penelitian Ghaffaar, et al., (2020). Terapi bekam memiliki efek menguntungkan pada pengurangan kolesterol total dan LDL-C serum serta meningkatkan kadar serum HDL-C pada wanita pasca menopause dengan hiperkolesterolemia. Hasil penelitian lainnya dari Norlita dan Wiradinata, (2020) terapi bekam berpengaruh terhadap penurunan kadar kolesterol dalam darah pada pasien hiperkolesterolemia di Thibbun Nabawi Center.

Berdasarkan data yang diperoleh dari uraian diatas peneliti tertarik untuk meneliti tentang efek terapi bekam basah terhadap penurunan kolerterol total pada penderita hiperkolesterolemia.

\section{METODE PENELITIAN Jenis Penelitian}

Penelitian ini merupakan penelitian kuantitatif dan desain yang digunakan dalam penelitian ini adalah Quasy Experiment pretest dan post-test pada satu kelompok saja.

\section{Waktu dan Tempat Penelitian}

Penelitian telah dilakukanpada tanggal 5 Oktober - 26 Desember 2020 bertempat di klinik Holistic Centre AsySyaafi

\section{Prosedur}

Penelitian ini dilakukan setelah mendapatkan perizinan dari klinik Holistic Centre Asy-Syaafi Palembang selaku tempat penelitian dan persetujuan dari responden. Terapi bekam diberikan sebanyak satu kali 
pada titik meridian, sebelum diberikan terapi bekam maka diukur terlebih dahulu kadar kolesterol responden, setelah diberikan terapi bekam maka diukur kembali kadar kolesterol.

\section{Target/ Subjek Penelitian}

Populasi subjek penelitian ini adalah semua seluruh pasien hiperkolesterolimia di Holistic Centre Asy-Syaafi Palembang berjumlah 31 orang. Lebih lanjut sampel pada penelitian ini diambil dengan tehnik total sampling yaitu seluruh pasien hiperkolesterolimia berjumlah 31 orang responden.

\section{Data, Intrumen, dan Teknik Pengumpulan Data}

Penelitian ini menggunakan data primer meliputi kadar kolesterol sebelum dan kadar kolesterol sesudah diberikan perlakukan. Adapun instrument yang digunakan dalam penelitian ini adalah lembar oberservasi kolesterol dan alat ukur kadar kolesterol yang digunakan adalah alat cek kolesterol. Pengumpulan data dilakukan dengan cara pengukuran langsung

\section{Teknik Analisis Data}

Analisa data pada penelitian terbagi menjadi 2 yaitu analisa univariat untuk mendapatkan mean, standar deviasi, confidance interval dari kadar kolesterol sebulum dan sesudah diberikan terapi bekam. Analisa bivariat dengan menggunakan uji paired sample t-test untuk mengetahui adanya pengaruh pemberian terapi bekam terhadap kadar kolesterol.

\section{HASIL PENELITIAN DAN PEMBAHASAN}

\section{Analisis Data Univariat}

Analisis data univariat dilakukan untuk mendapat sebaran data meliputi mean, standar deviasi, CI 95\% selanjutnya dapat dilihat pada table 1 .

Tabel 1. Analisis univariat $(n=31)$

\begin{tabular}{l|c|c|c|c|c|}
\hline Variabel & \multicolumn{3}{c}{ Mean Median Std. dev } & \multicolumn{1}{c}{ C195\% } & Min-Max \\
\hline Kolesterol Sebelum & 218,3 & 218 & 7.88 & $215,4-221,2$ & $206-231$ \\
\hline Kolesterol Sesudah & 209,03 & 208 & 5.31 & $207,1-210,9$ & $201-219$ \\
\hline
\end{tabular}

Table 1 menunjukan bahwa rerata kadar kolesterol sebelum diberikan terapi bekam adalah 218,3 \pm 7.88 , nilai median adalah $218 \mathrm{mg} / \mathrm{dl}$ kadar kolesterol terendah adalah 206mg/dl dan kadar kolesterol tertinggi adalah $231 \mathrm{md} / \mathrm{dl}$. Sedangkan setelah diberikan terapi bekam rerata kadar kolesterol 209,03 \pm 5.31 nilai median: $208 \mathrm{mg} / \mathrm{dl}$, kadar kolesterol terendah adalah $201 \mathrm{mg} / \mathrm{dl}$ dan kadar kolesterol sesudah $219 \mathrm{mg} / \mathrm{dl}$.

\section{Analisis Data Bivariat}

Analisis data bivariat dilakukan dengan uji paired sample t-test untuk mengetahui pengaruh terapi bekam terhadap kadar kolesterol responden dikarenakan data terdistribusi secara normal, untuk lebih jelas dapat dilihat pada Table 2 .

\section{Tabel.2 Analisis Data Bivariat}

\begin{tabular}{l|c|c|r|r}
\hline Variabel & \multicolumn{2}{l}{ Mean Std.dev } & Cl 95\% & p-value \\
\hline Kolesterol Sebelum & 218,30 & 7.88 & $215,4-221,2$ & 0.00 \\
\hline Kolesterol Sesudah & 209,03 & 5.31 & $207,1-210,9$ & \\
\hline
\end{tabular}

Table 2 menunjukan bahawa terdapat penurunan rerata kadar kolesterol 9,2 mg/dl. Sebelum diberikan terapi bekam kadar kolesterol adalah $218.30 \pm 7.88$ dengan CI 95\% 215.4-221.2 sedangkan rerata kadar kolesterol setelah diberi terapi bekam menjadi 209,03 \pm 5.31 dengan CI 95\% 207,1210,9 . Nilai p : 0.000 menunjukan bahwa ada perbedaan kadar kolesterol sebelum dan sesudah diberikan terapi bekam.

Hasil penelitian ini sejalan dengan penelitian yang telah dilakukan oleh Arozi dan Wibowo, (2018) menjelaskan bahwa adanya suatu pengaruh terapi bekam 
terhadap kadar kolesterol total pada pasien hiperkolesterolemia. Lebih lanjut hasil penelitian Helma, dkk (2018) mengungkapkan bahwa kadar kolesterol total setelah terapi bekam lebih rendah dari kadar kolesterol total sebelum terapi bekam. Terdapat perbedaan bermakna kadar kolesterol total sebelum dan sesudah terapi bekam (p:0.001).

Menurut Hasina dan Haryani (2021) salah satu terapi nonfarmakologi yang secara signifikan dapat mempengaruhi penurunan kadar kolesterol darah adalah terapi bekam, terapi ini juga merupakam salah satu sunnah Rasuluallah SAW dalam pengobatan. Nabi Muhammad SAW pernah bersabda "Kesembuhan bisa diperoleh dengan tiga cara, yaitu minum madu, hijamaah (bekam), dan besi panas. Aku tidak menganjurkan umat-Ku dengan besi panas." (H.R. Bukhari dan Muslim).

Hasil penelitian didukung teori yang dikemukan Umar (2019) menjelaskan bahwa cupping trerapy atau terapi bekam merupakan prosedur terapi yang dilakukan secara vakumisasi (adanya penyedotan bertekanan negatif) pada area kulit menggunakan alat penyedot. Terapi bekam ini bertujuan untuk membersihan serum trigliserida yang signifikan, kolesterol total, kolesterol LDL, ferritin, asam urat, autoantibodi, reseptor sitokin,dan lainnya. Terapi bekam bekerja dengan cara membersihkan darah dari kenaikan zat-zat, misalnya zat besi atau zat patologis, seperti autoantibodi. ( El-Sayed, 2013)

Menurut Ridho (2013) penurunan kadar kolesterol terjadi setelah mendapat bekam merupakan suatu dampak pada saat perlukaan ringan menyebabkan rangsangan nyeri yang selanjutnya sensor oleh motor neuron dikirim ke thalamus kemudian diteruskan melalui system syaraf simpatis terlepaslah ACTH, endorphin, kortison, dan lainnya. Disamping itu juga adanya perlukan ringan pada titik bekam dapat menimbulkan penurunan serum lemak trigliserida kolesterol LDL dan fosfolipida.

Berdasarkan hasil penelitian, penelitian terkait, dan teori penunjang maka peneliti berpendapat bahwa

KESIMPULAN

Berdasarkan hasil penelitian yang telah dilakukan, maka diperoleh kesimpulan bahwa terapi bakam dapat menurunkan kadar kolesterol darah.

\section{SARAN}

Disarankan kepada peneliti selanjutnya untuk melakukan penelitian pengaruh bekam terhadap penurunan kolesterol darah dengan metode yang berbeda. Diharapkan adanya Pendidikan kesehatan kepada masyarakat tentang manfaat terapi bekam serta cara mengontrol kadar kolesterol darah.

\section{UCAPAN TERIMA KASIH}

Penulis mengucapkan terima kasih kepada semua pihak yang terkait yang telah membantu mendukung terlaksananya penelitian ini.

\section{DAFTAR PUSTAKA}

Arozi, E. Z. A., \& Wibowo, T. A. (2018). Pengaruh Terapi Bekam Terhadap Kadar Kolesterol Total Pada Pasien Hiperkolesterolemia Di Klinik Pengobatan Islami Refleksi Dan Bekam Samarinda.

El-Sayed SM, Mahmoud HS and Nabo MMH. 2013. Medical and Scientific Bases of Wet Cupping Therapy; in Light of Modern Medicine and Prophetic Medicine. Alternative and Integrative Medicine 2: 1-16.

Faizal, Kgs M. Rezka Nurvinada., dan Zupera. 2020. EfekTerapi Bekam Terhadap Kadar Kolesterol. Malahayati Nursing Journal, P-ISSN: 2655-2728, E-ISSN: 2655-4712, Volume 2, Nomer 2 Maret 2020: hal 259-267 
Fikri, Z., Nursalam, \& M, E. M. (2017).

Penurunan Kadar Kolesterol dengan

Terapi Bekam

Hasina, S. N., \& Hariyani, E. C. (2021). Terapi Bekam Berpengaruh terhadap Penurunan Kadar Kolesterol Darah Total. Jurnal Keperawatan, 13(1), 1118.

Helma, H., Yaswir, R., \& Lillah, L. (2018). Pengaruh Terapi Bekam terhadap Kadar Kolesterol Total. Jurnal Kesehatan Andalas, 7, 50-53.

Kementerian Kesehatan Republik Indonesi (Kemenkes Ri). (2016). Riset Kesehatan Dasar.

Norlita, W., \& Wiradinata, D. I. (2020). Pengaruh Terapi Bekam terhadap Kadar Kolesterol Pasien Hiperkolesterolemia di Thibbun Nabawi Centre RSIA Zainab Pekanbaru Tahun 2019. Photon: Jurnal Sain dan Kesehatan, 10(2), 125-136.

Price, S.A., Wilson, L.M. (2015). Patofisiologi Konsep Klinis ProsesProses Penyakit. Edisi VI. Jakarta: EGC.

Ridho A,A. 2012. Bekam Sinergi: Rahasia Sinergi Pengobatan Nabi, Medis Modern dan Traditional Chinese Medicine. Solo: Aqwamedika

Riset Kesehatan Dasar (Riskesdas). 2018. Badan Penelitian dan Pengembangan Kesehatan Kementerian RI tahun 2018. Diakses pada Agustus 2018.

Umar, Wadda A. (2019). Bekam Medik, Hijamah Dalam Perspektif Modern Prosedur Bekam Sarat Sesuai Standar Tindakan Medis. Jakarta: Thibbia.

Yani, M. (2015). Mengendalikan Kadar Kolesterol pada Hiperkolesterolemia. Jurnal Olahraga Prestasi, 11, 1-7. 